\title{
Couple's Narratives of Shared-Self, Possessions and Consumption Experiences
}

\author{
Phoebe Wong, The Hong Kong Polytechnic University
}

Margaret K. Hogg, Lancaster University

Markus Vanharanta, University College Dublin

Primary Contact Person:

Phoebe Wong, PhD

PolyU West Kowloon Campus

12/F, North Tower

Yau Ma Tei, Hong Kong

Tel: $+852-3746-0072$

Fax: +852-2363-0540

Email: spphoebe@ speed-polyu.edu.hk

Phoebe Wong is a Lecturer in Marketing and Public Relations at the School of Professional Education and Executive Development, the Hong Kong Polytechnic University. She gained her $\mathrm{PhD}$ from Lancaster University. She read General Linguistics at the University of Helsinki, Finland, both at undergraduate and postgraduate level, followed by postgraduate studies in Marketing at University College Dublin, Ireland. Her work has appeared in refereed journals including the Journal of Marketing Management, Industrial Marketing Management, the International Journal of Higher Education Research, and Public Administration and Policy in Asia-Pacific Journal and Higher Education.

Margaret K. Hogg is a Professor of Consumer Research and Marketing at Lancaster University. Before joining LUMS in 2004, she was a Reader in Consumer Behaviour at Manchester School of Management, UMIST. She read Politics and Modern History at Edinburgh University, followed by postgraduate studies in history at the Vrije Universiteit, Amsterdam and then by an MA in Business Analysis at Lancaster University. Her work has appeared in refereed journals including the Journal of Advertising, Journal of Business Research, Journal of Marketing Management and the European Journal of Marketing. She is a co-author of the fourth edition of "Consumer Behaviour: A European Perspective" (Pearson 2010).

Markus Vanharanta is an Assistant Professor in Marketing at University College Dublin, based in Singapore. His primary research interests are managerial expertise, the dark-side of marketing, price-fixing conspiracies and intuitive decision-making. Markus draws his main influences from the theories related to Naturalistic Decision Making, industrial networks and critical realism. After obtaining his $\mathrm{PhD}$ from Lancaster University, Markus stayed at Lancaster first as a Post-Doctoral Fellow before becoming a lecturer in the Department of Marketing. 


\title{
Couples' Narratives of Shared-Self, Possessions and Consumption Experiences
}

\begin{abstract}
How consumers use possessions and consumption to enact their shared-self has been underexplored in earlier consumer research. The purpose of this paper is to investigate the emergence of couple-level (or partnered) shared-self. A narrative research method was used in Hong Kong, which allowed for an inter-temporal narrative about the informants' important possessions. Our findings revealed key characteristics regarding the way in which informants' interpretations of shared selves developed over time. This included sharing and negotiating resources (e.g. a house or money) with their partners, integrating similar perspectives (e.g. interests and lifestyle) to their partners', and including their partners as part of the self. This study provides the basis for future research to see how these findings hold up at other stages of partnered relationships. This research provides a conceptualization - a temporal model of couples' shared-self - that could contribute to and enhance the existing literature on the interrelationship between possessions and the extended self.
\end{abstract}

Keywords: Consumption behaviour, Sharing, Shared-self, Possessions, Narrative Article Type: Research Paper 


\section{Couples' Narratives of Shared-Self, Possessions and Consumption Experiences Introduction}

How consumers construct their sense of self through possessions has received extensive attention in consumer research since Belk's (1988) seminal paper more than twenty years ago (e.g. Curasi 1999; Price et al. 2000; Tian and Belk 2005). Earlier consumer research on possessions and the extended self has focused primarily on either the individual level, examining the construction of self through possessions (Dittmar 1991; Richins 1994b; Schultz et al. 1989), or the collective level, exploring the negotiation of the self among family members through collective possessions (Commuri and Gentry 2000; Cotte et al. 2004; Epp and Price 2008). In addition, Lastovicka and Fernandez (2005) discuss how discovering shared commonalities such as sharing a common profession can lead to shared self. However, there is little understanding of how people use possessions and consumption to enact their partnered or couple-level shared-self in earlier consumer research. Belk and Rosa (2012: 32) suggest that "sharing binds a couple together through a desire for interdependence leading to a sense of mutual extended self". The purpose of this article is to contribute to this new line of enquiry regarding the concept of a couple-level shared-self (Budworth et al., 2008) in relation to the couple's possessions and consumption, responding to calls for more exploration into sharing and the shared-self (Belk, 2010). Self and possessions are one of the key areas in consumer behaviour as Belk (1988: 139) emphasizes that "we cannot hope to understand consumer behaviour without gaining some understanding of the meanings that consumers attach to possessions." We pose two primary research questions. First, how do couples construct their sense of shared-self through possessions and consumption over time (cf. Lastovicka and Fernandez, 2005)? Second, how do couples negotiate their resources at the couple-level, to allow for two individuals to become a couple over time? In addition, this paper provides an opportunity to extend previous work on 
possessions and the extended self (Belk, 1988). Accordingly, we contribute to a new understanding of the construction of shared-self in relation to possessions and consumption, and we invite further examination of the notion of shared-self on the couple-level.

We begin by reviewing the literature on self and possessions, sharing and shared-self, and the use of narratives. Selves and identities are embedded in discourse in the format and construction of stories (Georgakopoulou, 2002). We then outline the research design we used to collect and analyse narratives from couples about their possessions and consumption so that we could access discourses around the self in different settings. We present our findings from informants' stories about their important possessions and illustrate how they construct their shared-self through their narratives. We conclude by discussing our findings about the interrelationship between the shared-self, possessions and consumption.

\section{Possessions and the Self}

Belk (1988: 139) argues that "we are what we have is perhaps the most basic and powerful fact of consumer behaviour". Possessions are not only viewed as the extended self (Belk 1988; Dittmar 1992), but also as the artefacts of the self (Kleine et al., 1995) in the selfdevelopmental identity projects. Consumers construct, form and maintain different aspects of their selves (e.g. the personal self or social self) by retelling the stories about their possessions as a reflection of their identities. In other words, the self is comprised of different identities. For example, the social self may consist of identities as a husband, a father, a colleague and a friend. People have different identities that are salient at different times depending on situational contexts. Possessions, such as people's testimonies, indicate their histories and experiences, and symbolize their intangible memories, experiences and feelings of the past through tangible objects (Noble and Walker, 1997). In addition, possessions help people retrieve their intangible assets and narrate their sense of self, so that they find it easier 
to describe themselves, significant others and other reference groups through possessions (Holman, 1983).

Earlier consumer research studied people's possessions that were regarded as meaningful using the terms of "important" (Csikszentmihalyi and Rochberg-Halton 1981; Dittmar 1991; Hirchman and LaBarbera 1990), "special” (Price et al. 2000; Richins 1994b), “cherished" (Curasi et al., 2004), "favourite" (Schultz et al. 1989; Wallendorf and Arnould 1988) or "treasured" (Kamptner, 1995) in the contexts of the home (Epp and Price 2008; Price et al. 2000), workplace (Tian and Belk, 2005) or different cultural contexts (Eckhardt and Houston 2001; Mehta and Belk 1991). Earlier research has focused on the individual level, investigating how individuals construct their sense of self through possessions (Eckhardt and Houston 2001; Richins 1994b; Schultz et al. 1989), and on the family level, examining how individuals in a family use possessions to define and negotiate their sense of self collectively (Commuri and Gentry 2000; Cotte and Wood 2004; Epp and Price 2008). However, the interrelationship between possessions and the construction of shared-self at the dyadic level remain underexplored. Exploring how couples share and negotiate their possessions and consumption experiences will enhance our understanding of the current literature in consumer research.

\section{Sharing and Shared-Self}

Sharing is one of the key concepts in consumer behaviour, yet it seems to have been somewhat neglected in consumer research, and is often treated as either gift or commodity exchange (Belk, 2010). The concept of sharing is linked to ideas about how possessions are consumed and disposed (Lastovicka and Fernandez, 2005), in addition to how ownership and self are culturally shaped and influenced by societies. This line of research can be linked to the work of Gainer (1995), who identified how gender can influence shared consumption experiences and the creation of a shared-self. In addition, Lastovicka and Fernandez (2005) 
studied unrelated pairs of individuals transitioning from "me and you" to "we" through a seller-buyer dyad at garage sales and discovered that shared commonalities such as sharing a common profession (e.g. guitarists) or hobby (e.g. stamp collection) can lead to a shared self. Belk's (2010) explanations of sharing involve a merged aggregate extended self, and the prototype of sharing focuses on the tangible resources of sharing. He conceptualized sharing in terms of routine sharing (e.g. food and money), mothering (e.g. sharing the body with the fetus and providing milk for the infant) and sharing household resources within a family. However, Aron et al. $(1991 ; 2005 ; 1995)$ argue that people in close relationships tend to include their partners in the self, resulting in the expansion of the self. A close relationship involves not only sharing resources but also integrating close others' perspectives (e.g. interests and lifestyle) and incorporating them into the self.

The shared-self is based on the notion of incorporating close others into the self. Aron et al. (1992) suggest that people view close others as part of the self. Including close others in the self leads to an overlapping of selves, and thus, potentially, the expansion of the self. Aron et al. (2005: 209) note that "by entering a relationship one gains to some extent the other's resources, perspectives and identities. Instead of just being me, I am now both me and you". This expansion of the self can be constructed in the relationships of romantic/marital partners, parents and children (Connell and Schau 2010; Hwang 1999), and even close friends (Joy, 2001). As the last two sources here suggest, there may well be cultural differences, although romantic love, which may undergird some of this, appears to be a universal phenomenon (Jankowiak, 1997).

Sharing and the shared-self may be intertwined concepts. People construct their sense of shared-self through sharing their resources with others. In line with Aron et al.'s (1992) notion of including close others in the self, Agnew et al. (1998) explained how couples' behaviours and daily interactions shape their relationships and the construction of the self 
among them. Members of a couple share their resources (e.g. routine sharing) and influence one another's perspectives and personalities. People in close relationships tend to view their sense of self as shared-selves ("self-in-relationship") and that each member of a couple probably perceives the couple more as a "self-and-partner collective" rather than as separate individuals (Agnew et al. 1998; Budworth et al. 2008).

\section{Research Method: Narrative Research Design}

In the present study, informants were asked to share stories about their possessions that were special, meaningful and important to them. From informants' past experiences, they reflect on, and formulate who they are at present and who they might want to be in the future organizing their life with a temporal sequence (Chronis 2015; Stern et al. 1998). As Georgakopoulou (2002: 428) says, "if selves and identities are constituted in discourse, they are necessarily constructed in stories".

The informants were young Hong Kong Chinese professionals aged between 29 and 39 (Table 1) who had been married between 2 and 10 years. The rationale for choosing a nonWestern context is that Hong Kong as a society emphasizes the interdependent self-construal (Markus and Kitayama, 1991) and thus provides "the greater incidence of sharing rituals" (Belk 2010: 728) that will enhance our understanding of possessions and the shared-self. The basis for choosing this age group $(29$ - 39) was that intimate dyadic relationships play a significant role in young adults' self-definition (Erikson, 1982) and are often still in the early formative stages, so that individuals' memories of themselves before and after they became a couple allow insights into the evolutionary processes behind the emergence of the shared self. According to Erikson's stages of psychosocial development, adults in their young adulthood (i.e. the mid-twenties and thirties) are "... ready to pursue mature intimacy, a step that begins a new chapter in the life story" (Baddeley and Singer, 2007: 187). In line with previous interpretivist studies in consumer research that focus on a small number of informants (e.g. 
Ahuvia 2005; Eckhardt and Houston 2001; Fournier 1998), five couples (five males, five females) were identified for this study using the snowball technique.

Narrative interviews were conducted in Hong Kong that lasted on average one hour. The interviews took place in natural settings (e.g. homes) that enabled the researcher to develop an understanding of detail about the individual (Creswell, 2003). Joint interviews with couples might have provided insights into their interactions (e.g. by observing nonverbal modes of communication such as body language, and the interviewees' process of constructing a story together) (Pahl, 1989). However, joint interviews have also disadvantages: informants may not feel free to reveal stories in the presence of their partners, and, in particular, one informant may dominate the other (Arskey 1996; Radley 1988). More significantly, we recognized that even if a couple shares a self-concept and possessions, this outcome is likely to have emerged differently for both individuals, based on different starting points and different personal experiences. As a result, the inter-temporal journey from an individual self towards the shared self would have been largely lost had we interviewed couples together. Also, it was useful to interview couples individually in order to avoid influence from the partner when narrating stories about important possessions (Morris, 2001) and to gain insights into individual perspectives on coupledom (Boeije, 2002). Interviewing informants individually rather than jointly hence provided us with the appropriate narratives to address our research questions.

We began each interview by inviting informants to share their personal backgrounds and interests. In line with the interview design in prior consumer research (e.g. Richins, 1994b) and Wagner and Wodak's (2006) method of narrative interviewing, one key guiding question of "Tell me stories about possessions that are important to you" was used in the interviews. As Taylor (1989: 34) argues, "what I am as a self, my identity, is essentially defined by the way things have significance for me. To ask what I am in abstraction from self- 
interpretation makes no sense". It is suggested that people can express their feelings, emotions and thoughts through sharing stories about their possessions (Richins, 1994a). In addition, the flow of topics varied depending on each informant's life journey. Informants were free to share stories about important possessions relating to their personal self (e.g. achievements), relational self (e.g. being a good husband, son or friend) and collective self (e.g. a member of an organization) in order to gain a holistic picture of informants' construction of the self, and to avoid imposing a construction of the shared-self on them. In all, we collected 60 stories about informants' important possessions. However, in this paper, we will only concentrate on stories about their important possessions on the couple-dyad level (i.e. 26 stories $-43 \%$ of the dataset), as this is the focal point of the paper in order to understand how the shared-self is constructed in relation to possessions. All the interviews were digitally recorded and transcribed in full.

\begin{tabular}{|c|c|c|c|c|c|}
\hline $\begin{array}{l}\text { No. of } \\
\text { couples }\end{array}$ & Name & Gender & Age & Occupation & $\begin{array}{l}\text { Years of Marriage/ } \\
\text { Being together }\end{array}$ \\
\hline \multirow[t]{2}{*}{ Couple 1} & Sam & Male & 30 & Doctor & \multirow[t]{2}{*}{2 years/ 7 years } \\
\hline & Ada & Female & 29 & Law Student & \\
\hline \multirow[t]{2}{*}{ Couple 2} & Jake & Male & 39 & Accountant & \multirow[t]{2}{*}{7 years/ 10 years } \\
\hline & Shirley & Female & 34 & Flight attendant & \\
\hline \multirow[t]{2}{*}{ Couple 3} & Peter & Male & 36 & Engineer & \multirow[t]{2}{*}{9 years/ 18 years } \\
\hline & Danni & Female & 34 & Social worker & \\
\hline \multirow[t]{2}{*}{ Couple 4} & Winston & Male & 35 & Customs Officer & \multirow[t]{2}{*}{10 years/ 20 years } \\
\hline & Lucy & Female & 33 & Music teacher & \\
\hline \multirow[t]{2}{*}{ Couple 5} & Andrew & Male & 35 & Theology student & \multirow[t]{2}{*}{9 years/ 16 years } \\
\hline & Connie & Female & 34 & PE teacher & \\
\hline
\end{tabular}

\section{Table 1: Demographic Information about Informants}

The transcripts were read a number of times in order to attain understanding of the materials and to categorize evolving themes inductively (e.g. building romantic relationships, strengthening and cultivating relationships with partners, entering different life stages with their partners). Then, Clandinin and Connelly's (2000) three-dimensional narrative structural analysis was employed to examine the structure of informants' stories under the dimensions of interaction (i.e. exchanges with significant others on the social level), temporality (i.e. the 
impact of the past event or experience on the present self possibly influencing informants' future direction) and situations (i.e. time and context). After analysing how these informants told their stories about important possessions forming and reflecting on different aspects of the self, we present extracts from various informants' narratives for this paper demonstrating how the shared-self is constructed.

\section{Findings}

Data analysis yielded a number of themes that revealed how informants interpreted what constituted their important possessions and their shared selves. As informants were interviewed individually to avoid influence from their partners when narrating stories about important possessions, some couples narrated stories about the same possessions while other couples chose different possessions to discuss. Aron et al. $(1991 ; 1995 ; 2005)$ suggest that people not only share resources (e.g. routine sharing - food and money) with their partners, but also integrate close others' perspectives (e.g. interests, values and lifestyle) into their selves. In addition, people in couples view their partners as parts of their selves, and this supports their construction of their relationship. In this section, we examine informants' construction of the shared-self through stories about their important possessions from three dimensions: firstly "sharing resources with their partners", secondly "sharing perspectives with their partners" and thirdly "sharing identities as couples".

\section{Dimension 1: Sharing Resources with Partners}

Informants construct their lived experiences with their partners in their daily lives. Sharing can be viewed as a communal act that binds people together (Belk, 2010). Sharing resources with partners is a common theme in the findings. Informants' stories captured tensions in terms of how informants allocated and negotiated their resources in different life transitions that emerged from the narratives. In the following excerpt, Andrew shared a story about his first house that he no longer owned. From dating through to marriage, Andrew was excited to 
have a new chapter in his life with his beloved wife, Connie. Andrew described in detail how he and Connie had constructed their lives together as a married couple by building their first home together. They used almost all their savings to build their dream home and thought they would "live there forever". Andrew used the house as a symbol to define his sense of sharedself in a new stage of life with Connie as well as an indicator of the completeness of a married couple (Gollwitzer and Wicklund, 1985).

Andrew: It was the first house we bought. We felt that that was OUR house. We chose the colour of the tiles and the glass... When we got the house, we thought we needed to equip it with the best, because it is your house. Prepare... equip the house with the best items.

A few years later, Andrew had the calling to study theology and to dedicate himself to his church. After various retreat camps, and serious discussions with Connie, Andrew made up his mind to give up his job as a PE teacher and to enrol himself in the Christian ministry and study theology for three years. As a result, Andrew and Connie decided to sell their dream house and use the money to support Andrew's studies. Although the financial burden fell on Connie's shoulders, she did not complain about using her salary to support Andrew financially to help him fulfil his dream. In fact, Connie was very proud of her husband's decision. As Andrew said, "I really have to thank Connie for her unconditional support and patience. The family... that is the most important thing." In part, the ease with which Connie made the sacrifice related to the couple's shared religious beliefs, whereby Connie saw a deeper spiritual purpose (or a divine guidance) which encouraged her to support her husband's theology studies. In addition, through her husband's theology studies, Connie was also making a personal transformation to become a minister's wife. The previous shared selfconcept related to the family house, was hence transformed to different type of shared self and identity.

Another informant, Sam, also described how he constructed his shared-self through narrating stories about two of his important possessions, his BMW car, which he no longer 
owned, and his gift of an engagement ring to his wife, Ada. Two identities are important in Sam's self-definition, his professional identity (the personal dimension of the self) (Brewer and Gardner, 1996) as a doctor and his identity as a husband for Ada (the relational dimension of the self). When these two identities conflicted with one another, Sam had to choose between the two. This tension in negotiating resources was captured in his narrative when Sam described the process of selling his first dream car in order to generate extra money for the wedding. Sam was in a dilemma between his two conflicting identities of an aspiring doctor, through his acquisition of his BMW (his personal dimension of the self), and a loving husband for Ada, through the means of generating resources (i.e. money) for an engagement ring and an expensive wedding (his relational dimension of the self). Sam did not want to let go of the car, because he felt that he would lose part of his identity as a successful doctor. However, at the same time, he realized that he had to move on from his life as a single man and tried to reason himself out of the situation. Although this ring does not belong to Sam, he regarded it as one of his important possessions.

Sam: I decided to sell the car and used the money to buy her the ring. When I saw my car driven away, I was really sad. The night before the car was driven away, we [Sam and Ada] sat in the car and listened to music... polished the car... talked to the car... took some photos. I really miss the car. We called our car Siu Po [meaning Little Precious]... Every stage of your life has different desires; I have already fulfilled my desire to have a BMW. It is time to let go. I bought this BMW to reward myself for studying really hard for the previous five years... What I am doing now is for my future, ten years onward. I thought about it back and forth and decided to sell the car so that we would have spare money to spend on our wedding. Also, it doesn't make sense if I like the car more than her. How can you love an object more than this person?

These activities can be seen as a divestment ritual, similarly to the description of Lastovicka and Fernandez (2005). In this case, however, it is important to note that the car was Sam's sacred possession (Belk et al., 1989), not Ada's. By participating in this divestment ritual, Ada demonstrated her appreciation and empathy in relation to Sam's sacrifice, whereby the sacrifice acquired additional significance. Thus, as the couple spent their last night jointly 
sitting in the car, listening to music, polishing the car, talking to the car, and taking photos, Ada demonstrated her empathy towards Sam, recognizing his painful sacrifice for them as a couple. Without this empathy and joint participation in the divestment ritual, the sacrifice would not have had a similar level of meaning and power in strengthening the couple's shared self in the narrative. However, by participating in the divestment ritual, Sam's sacrifice acquired a symbolic meaning in their relationship, which was then in part transferred to the ring bought with the proceeds. Also, Ada's participation in the divestment ritual (witnessing Sam's deep attachment towards the car and the following grief of separation) made the ring a more powerful reminder of Sam's sacrifice, and of the fact that Sam had valued his wife more than his most precious material possession, the BMW.

\section{Dimension 2: Sharing Perspectives with Partners}

Apart from sharing resources with their partners, informants' narratives also reveal how they share and integrate their partners' perspectives (e.g. interests, lifestyle and values) in the construction of their shared-self. Some couples can maintain separate interests and still merge with each other through certain other possessions. However, couples often influence each other's consumption style as they gradually share or fuse their interests.

In the narratives of Peter and Danni, as their relationship developed, their consumption started reflecting their increasingly shared interests. The theme of sharing an interest in collecting Swatch watches is illustrated in the following excerpt. Peter is a serious fan of Swatch and has at least 80 Swatch watches in his collection. However, as Peter and Danni became a couple, they both constructed their narratives in a way that allowed the Swatch collection to become (in part) their shared possession. Also, Peter's interest in Swatch watches became the couple's shared interest. As such, Swatch watches became a resource that strengthened Peter's and Danni's couple narratives. First, Peter shared a story about a Swatch watch that signified his loving relationship with his wife, Danni. The Swatch watch was a 
surprise gift that Peter had given to Danni on their anniversary. Although this Swatch does not belong to Peter, he still regards it as an important possession. Peter explained how he prepared the gift for Danni. As Pierce et al. (2003) suggested, one of the ways by which people develop ownership feelings towards an object is by investing themselves (e.g. their time, money or effort) into the object. In Peter's case, he invested his effort, and sacrificed his time and money, to plan and present this surprise gift to Danni (Belk \& Coon, 1993). Peter used a tangible object to deliver an intangible yet important message of love. The watch bears symbolic and emotional meanings of affection to Danni. This gift-giving served to strengthen their relationship (Areni et al. 1998; Ruth et al. 2004).

Peter: It was an anniversary present. I didn't expect her to have such a huge reaction. I remember we went to a shop and saw this one and said this one was quite nice. She didn't know I would buy it for her. I bought it and put it on the table before I went to work because she came home before me. When she came home and found the present on the table, she was really happy. I didn't expect her to be that happy... I used a piece of our wedding ceremony program to write a few sentences and attach them to the present.

Under the influence of Peter, Danni, in a separate interview also shared a story about two Swatch watches that she regarded as important possessions in the following excerpt. These two Swatch watches mark a rite of passage in becoming an adult, as she bought them with her first salary payment. Sharing Peter's interest in Swatch watches, Danni rewarded herself for her personal accomplishments by buying herself two watches (Mick and Demoss, 1990).

Danni: Swatch... I bought Swatch when I got my salary for the first time. It was memorable because it was the first time I received money I had earned myself... [This gave me] a sense of satisfaction. The feeling was quite interesting coz I felt happy but at the same time I realized it was not easy to earn money... I wanted to buy something to reward myself with my own money... I deserved it... so I went to buy something.... Swatch was quite big at that time. Also because of Peter... I bought two watches at the same time. Both of them were Swatch.

Not only do the Swatch watches mark Peter's and Danni's romantic history in the past (the past shared self), and represent the present moment of their shared attachment towards 
Swatch watches (the present shared self); they also symbolize their promising future together (the future shared self) (Schultz et al., 1989).

In addition to sharing interests and consumption experiences, informants also shared similar values and attitudes to life. The following excerpt from Ada illustrates that couples tend to share consumption experiences as well as similar lifestyles. Ada shared her story about a watch that she received from Sam as her story about an important possession. The watch not only symbolized their enjoyable time together in the UK, but also reminded them of their efforts in working hard in order to indulge and reward themselves by treating themselves to a nice holiday. Ada further explained the reason both of them came to share similar attitudes towards luxury consumption by revealing her sense of shared-self ("we"). A shared-self ("we") stands out more prominently than the individualistic self ("I") in her narrative:

Ada: I didn't have any watch to wear while travelling in England. So Sam bought it for me. We had a good time there... [It was a] real holiday for me. It was the first time we travelled to England. We went to major touristy places and had good food in the evenings. We spent rather a lot of money on food, hotels, and good restaurants. We share the same passion for good food... The reason why we [Ada and Sam] always want either the best or nothing is our "grown-up" attitude that we have to work hard in order to achieve something... We just want to be the best in our standard. Within what we can choose, we want the best.

In a separate interview, Sam elucidated how this couple's materialistic lifestyle developed because of their backgrounds. He felt it was justifiable that both of them could indulge themselves in different consumption goods (e.g. a holiday or a car) because of their hard work. Both Sam and Ada construct their own sense of shared-self ("we") through consuming goods as rewards that mark their achievements and motivate them to work harder (Mick \& DeMoss, 1990).

Sam: Neither of our families are rich. We studied really hard, "beat everybody" and strived for our better futures. I graduated with a distinction. Ever since we were little, we had no chance of such a materialistic lifestyle. But now we have such a choice. We want to have the best this time. Grand wedding... spending money... I can afford it. 
What I have at the moment - a stereo system, a car and a computer - is what I studied hard for.

\section{Dimension 3: Sharing Identities as Couples}

Other stories reveal that informants, apart from sharing perspectives (e.g. interests, lifestyle and values) with partners, construct their sense of shared-self together as a couple through remembering particular experiences involving their important possessions. For example, the husband and wife relationship is regarded as a necessary relation, in which "each part of the relation cannot exist as such without the other" (Sayer, 1992: 89), and is viewed as the construction of the shared-self. Informants seem to narrate stories about the same possessions when creating and constructing identities as a husband and a wife. This theme is illustrated in the following quotes from Jake and Shirley. In separate interviews, Jake and Shirley shared a story about a diamond cross pendant. Jake told a story about a diamond cross pendant that he had bought for his then girlfriend (now his wife), Shirley, for her baptism, revealing his relational dimension of the self, a husband-wife relationship. In addition to the symbolic meaning of the necklace (relating to Shirley's being a Christian), there were thereafter additional lived experiences, including an incident when the pendant was dropped down the sink. This experience has taught both Jake and Shirley that it is better to solve problems together as husband and wife than alone. The cross pendant carried not only its original culturally shared meaning, celebrating Shirley's baptism, but also an additional idiosyncratic experientially-derived meaning that they will always share (Ruth et al., 1999).

Jake: I gave it to her on her baptism. For her... and me, it is very memorable. We experienced and learnt something from that incident... It is always better to solve a problem together, i.e. as a husband and wife, than as a person alone... The meaningful part is lost and found experience... She took the necklace off and accidentally dropped the pendant into the sink.... She spent the whole night trying all kinds of methods to get it out but failed. Finally, she woke me up and told me with tears that "I am really sorry..."... Then we both tried again with all kinds of methods and finally got it out... The necklace itself is very meaningful, even apart from this incident of solving the problem together. She really cherishes the necklace. She wears it every day and never takes it off. 
Shirley also narrated this story about the diamond cross pendant in a separate interview. It had a symbolic meaning, because now she was a Christian with a cross around her neck. In Shirley's narrative of the incident, she emphasized how she had failed to solve the problem alone and how she had learned the benefit of dealing with problems together. This experience helped them build up a stronger relationship together. From now on, when Jake and Shirley face difficulties, they will remind themselves of this incident and how they solved it together as a couple. Hence an experience from the past will carry a significant meaning in their future. As Kleine et al. stated (1995: 327), “a special possession could facilitate self-continuity by connecting a person with a desirable past self (e.g. memories), a present self (me now), or a future self (who I am becoming)".

Shirley: Jake gave it to me on the day of my baptism to celebrate that I had become a Christian. I dropped it in the sink and it took me the whole night to retrieve it... Now when I think about it, it is still quite sad, because it took me the whole night and I felt really down... I did not want to wake Jake up. I thought he could not help me. I thought men are careless. How wrong and silly I was! In the end, we had to solve the problem together and got the pendant out of the sink's drainage tube. Jake did it with some Blu-Tack... I couldn't get it out by myself. It was him who did it for me. That was an experience where we learned... to try to solve problems together.

In addition, some informants have important possessions that revealed a particular stage in their relationships. They share their histories and build their memories together through their possessions (Belk 1988; Richins 1994b) when constructing their identities as a dating couple. Possessions serve the purpose of enhancing and strengthening informants' relationships with their romantic partners (Ruth et al. 1999; Schultz et al. 1989), and carry significant symbolic meanings in creating and maintaining their relationships as romantic couples. The theme of maintaining a shared-self among couples is illustrated by Winston and Lucy's stories about their set of Everlasting Love watches. Winston and Lucy's consumption and gift-giving patterns have changed as they have entered into a more established relationship. At the beginning of their relationship, both of them would spend a lot of time planning what to buy and when to give gifts to each other in order to surprise each other. As their relationship 
became more established, Winston and Lucy tended to be more open and spontaneous about their consumption as a dating couple. They purchased a joint gift of a Titus Everlasting Love series watch set together as a relationship announcement. As Huang and Yu (2000: 182) comment, "through the mutual possession of gifts in kind, lovers communicate to the outer world about their relationship. Here, gifts are used to convey public meanings and are beneficial to a relationship". This watch set not only has a culturally shared symbolic meaning, being one of the most popular watches at that time in Hong Kong, but also carries the couple's special idiosyncratic and shared symbolic meaning, indicating their stable and close relationship (Montgomery 1988; Ruth et al. 1999).

Winston: The lover watch set... is the one we bought together... The Titus Everlasting Love series watch set. It was a big hit in Hong Kong in the 90s. All lovers had a pair... It was like a hot item you got to give it to your girlfriend or boyfriend. Lucy liked the TV commercial very much because it was very touching and romantic... Comparatively, I guess it is more important for her to wear them, because she liked that, sort of, symbolic meaning of the watch... everlasting love. At that time, we wore them together when going to church.

Lucy, in a separate interview, told a story about these items that recorded the development of this couple's dating relationship with a different emphasis. She recalled her memories of being separated from Winston while he was pursuing his undergraduate studies in the UK. Before Winston left, Lucy was very dependent on him for decision making and paying bills. Her identity as a very dependent girlfriend was in the process of changing during this period. That was the first time they had had to be apart, leaving Lucy to be strong and independent without Winston's presence. They bought a set of Everlasting Love watches in order to confirm their love for each other and to remind themselves of their love and commitment. This lover set of Titus watches, whose TV commercial promoted its slogan Everlasting Love, symbolized their love, and they could wear them when they were apart. Lucy spent a lengthy time in the interview narrating the story of Everlasting Story in the commercial. She seldom throws away possessions that belong to both of them as a couple, as she cherishes them as 
recalling the web of ups and downs in the history of their relationship (Belk 1991; Olson 1985).

Lucy: Then our set of (Everlasting Lover) watches. We bought them at City Chain [a watch shop in Hong Kong]. Nothing really special... Ahh! It is "Tian Chang Di Jiu" [The 'Everlasting Love' Titus watch advertisement slogan]. That advertisement... You know... With the male model... and Anita Mui [a Hong Kong Chinese pop music star] on the TV commercial... the old Shanghai train station, and their glamourous clothing... They were saying goodbye at the train station, before they were separated. The guy gave the watch to Mui and said something about love forever. It is the effect of the advertisement... You know, "Everlasting Love". It's a pair [of watches]. I still have them and have not thrown them away."

\section{Discussion}

Based on the findings, we conceptualize a temporal model capturing key aspects of the couples' shared-self consumption narratives (Figure 1).

\section{"Take in Figure 1"}

As a common theme in our findings, the narratives of shared possessions helped two previously unrelated individuals to transition closer together, moving from "me and you" to "we". In the couples' narratives there was hence a temporal movement which shifted the prioritization away from personal self-concepts (past), towards shared-self concepts (present and future). Accordingly, these narratives related to shared resources and perspectives, and ultimately to their shared identities (Figure 1).

Also, the couples' narratives helped to organize life with a temporal sequence of past, present and future (Daiute and Lightfoot, 2004: xi). However, this movement towards a shared-self often required considerable sacrifices and trade-offs. As a result, the narratives described various compromises and (internal) negotiations weighed what was truly important in the respondents' lives, including anxiety related to the loss of personal possession and gratitude towards their partner's sacrifices. The observed couple narratives were hence an 
account of the negotiations, prioritizations, compromises, construction of coherence, and integration of different elements into a coherent story (Therkelsen and Gram, 2008). Based on their past experience, couples tended to reflect on and formulate who they were in the past, and how they made the transition into couples (today and the future) (Chronis 2015; Stern et al. 1998). For this purpose the couple narratives provided a sense of continuity between past, present, and future. This type of narrative construction where partners are actively working to bring themselves closer together can be seen as an indication of a healthy relationship or as a couple's desire to strengthen their relationship (Figure 1). In contrast, we can conjecture that couples who are breaking up may engage in the opposite type of narrative that transitions previously related partners into separated ex-couples.

Andrew's story about his house being part of his important possessions reveals how he and Connie went through a negotiation process about the allocation of their resources, sharing numerous discussions and attending different retreat camps to search for answers, before selling their house to support his study. This example illustrates that members of the couple shared resources and sought to maximize their chances of attaining their joint goals. But also the construction and negotiation of shared self among couples can be seen as continuous process of negotiation, whereby its meaning may change over time depending on events in different life stages and dynamic interactions in the couple's environment (Budworth et al., 2008).

Both Andrew and Sam needed to make a decision or to take action in choosing between keeping the possessions that signified their past shared selves (a house and a car, respectively), and disposing of them in order to make changes in their lives. These possessions carried significant meanings that symbolized particular transitions in their lives (Belk et al., 1989). For example, Andrew thanked Connie for agreeing to sell their first house in order to support his theological studies, and Sam sold his car in order to finance his 
wedding with Ada. Most of the time, disposition happens when people face major changes and life transitions (e.g. graduation, moving house, marriage, parenthood and death) (Gentry et al. 1995; McAlexander 1991; Young 1991). People go through the process of disposition for numerous reasons, for example, to adapt to a new environment (e.g. moving home) (Epp and Price 2008) or to deal with changes in their life transitions (Curasi et al. 2004; Price et al. 2000). When informants narrated the process of disposition in their stories, they were caught in a dialectic tension and often had ambivalent emotions (Schouten, 1991).

The couple narratives also allowed informants to transition closer to each other, in terms of similar perspectives with their partners, such as interests (Peter and Danni share an interest in collecting Swatch watches) and lifestyle (Sam and Ada enjoy their material lifestyle). As Baddeley and Singer (2007) suggest, “(w)ithin established relationships such as marriages, partners continue to build, revise, and reinforce a mutually understood set of values and meanings system" (p. 188). In an interpersonal romantic/marital relationship, a person's self tends to overlap with his/her partner's (Aron et al. 1992). In other words, the self is viewed as "the self-in-relationship" (Budworth et al. 2008: 106), indicating that partners view themselves less as two individuals but more as one unit - "self-and-partner collective" (Budworth et al. 2008: 106). In Sam and Ada's story about their holiday trip to Europe, a shared self "we" stands out as more significant than the personal self "I". Both Sam and Ada often used the pronoun "we" instead of "I" in their narratives, suggesting that they viewed their sense of self as "self-and-partner collectives" (Budworth et al. 2008: 106).

In addition, our findings also reveal that informants seem to have a broader interpretation of the boundary between the extended self and possessions (i.e. what constitutes ownership of what might be called the extended possessions) (Wong and Hogg, 2010). Our research shows that most of the informants narrated stories about important possessions that actually belonged to their partners, not themselves (e.g. Sam's gift of an engagement ring to 
Ada; Jake's gift of a cross pendant to Shirley) as among their own important possessions and thus part of their shared selves. Rudmin (1994) argues that people are ready to extend the concept of ownership beyond its tangible and factual bounds and criticizes traditional definitions of ownership for not capturing the essence of this concept. Our findings show that gift-giving to romantic partners reinforces bonds of love (Areni et al. 1998; Belk 2010; Hollenbeck et al. 2006; Sherry 1993). Informants who regard their gifts to their partners as their own possessions feel this attitude is justified by their having prioritized the needs of their partners by pleasing and satisfying them. Although informants did not physically or legally own the objects that belonged to their significant others, to a certain extent they morally “owned” them. Using Yang's (1994: 297) explanation of gifts in his observation of Chinese gift-giving, there is always "a little of you in me and a little of me in you".

\section{Conclusion}

The purpose of this study was to gain insights into the consumer's construction of shared-self through stories about possessions and consumption experiences. Our informants' narratives demonstrate how two previously unrelated people use shared possessions, either daily use objects (e.g. a diamond cross pendant) or joint life projects (e.g. a house), as a means to move closer together as couples. These inter-temporal narratives described various compromises and (internal and external) negotiations weighed what was truly important in the informants' lives. This included negative emotions related to the loss of personal possessions and gratitude regarding the sacrifices their partners made in relation to shared possessions. The observed couple narratives included compromises, negotiations, prioritizations, construction of coherence, and the integration of different elements into a consistent story. In this research, the informants shared their innermost feelings about possessions linked to their relationships with their partners signifying who they were, how they became who they are, and sometimes also who they want to be in the future. 
The limitations of individual interviews can be overcome by future research combining individual and joint interviews in order to develop a holistic perspective of the shared-self. Collecting and analysing consumer narratives has allowed us to reach for deeper understanding in terms of how informants interpret the meaning of possessions and how they view their shared-selves through stories about objects they consider important. In future research, it would be interesting to investigate what kind of identities couples may or may not share and how these findings hold up at other stages of relationships, such as divorce or remarriage, as well as how they differ cross-culturally, in inter-cultural marriages and in different types of relationships (e.g. lesbians and gay men, best friends, parents and children). 


\section{References:}

Agnew CR, Lange PAM, Rusbult CE, Langston CA. 1998. Cognitive interdependence: commitment and the mental representation of close relationships. Journal of Personality and Social Psychology 74(4): 939-954.

Ahuvia AC. 2005. Beyond the extended self: loved objects and consumers' identity narratives. Journal of Consumer Research 32(June): 171-184.

Areni CS, Kiecker P, Palan KM. 1998. Is it better to give than to receive? Exploring gender differences in the meaning of memorable gifts. Psychology and Marketing 15(1): 81109.

Aron A, Aron EN, Smollan D. 1992. Inclusion of other in the self scale and the structure of interpersonal closeness. Journal of Personality and Social Psychology 63(4): 596612.

Aron A, Aron EN, Tudor M, Nelson G. 1991. Close relationships as including other in the self. Journal of Personality and Social Psychology 60(2): 241-253.

Aron A, Mashek D, McLaughlin-Volpe T, Wright S, Lewandowski G, Aron EN. 2005. Including close others in the cognitive structure of the self, in Mark W. Baldwin (ed.), Interpersonal Cognition. Guilford Press: New York; 206-232

Aron A, Paris M, Aron EN. 1995. Falling in love: prospective studies of self-concept change. Journal of Personality and Social Psychology 69: 1102-1112.

Arskey H. 1996. Collecting data through joint interviews. Social Research Update 15: 1-4.

Baddeley J, Singer JA. 2007. Charting the life story's path: narrative identity across the life span, in D. Jean Clandinin (ed.), Handbook of Narrative Inquiry: Mapping a Methodology. Sage: London

Belk R. 2010. Sharing. Journal of Consumer Research 36: 715-734.

Belk R, Rosa L (eds.). 2012. The nature and effects of sharing in consumer behavior. Taylor \& Francis: London

Belk R, Wallendorf M, Sherry JF. 1989. The sacred and the profane in consumer behaviour: theodicy on the odyssey. Journal of Consumer Research 16(1): 1-38.

Belk RW. 1988. Possessions and the extended self. Journal of Consumer Research 15: 139168.

Belk RW. 1991. Possessions and the sense of past. Paper presented at the Highways and Buyways: Naturalistic Research from the Consumer Behaviour Odyssey, Provo, UT.

Belk RW, Coon GS. 1993. Gift giving as agapic love: an alternative to the exchange paradigm based on dating experiences. Journal of Consumer Research 20 (December): 393-417.

Boeije H. 2002. A purposeful approach to the constant comparative method in the analysis of qualitative interviews. Quality and Quantity 36: 391-409.

Brewer MB, Gardner W. 1996. Who is this "we"? Levels of collective identity and self representations. Journal of Personality and Social Psychology 71(1): 83-93.

Budworth MH, Enns JR, Rowbotham K. 2008. Shared identity and strategic choice in dualcareer couples. Gender in Management: An International Journal 23(2): 103-119.

Chronis A. 2015. Substantiating byzantium: the role of artifacts in the co-construction of narratives. Journal of Consumer Behaviour 14(3): 180-192.

Clandinin DJ, Connelly RM. 2000. Narrative Inquiry: Experience and Story in Qualitative Research. Jossey-Bass: San Francisco.

Commuri S, Gentry JW. 2000. Opportunities for family research in marketing. Academy of Marketing Science Review 2000(8): 1-34. 
Connell PM, Schau HJ. 2010. The pursuit of identity augmentation: self-expansion and selfextension as distinct strategies. Paper presented at the Advances in Consumer Research, Duluth, MN.

Cotte J, Ratneshwar S, Mick DG. 2004. The times of their lives: phenomenological and metaphorical characteristics of consumer timestyles. Journal of Consumer Research 31: 333-345.

Csikszentmihalyi M, Rochberg-Halton E. 1981. The Meaning of Things: Domestic Symbols and the Self. Cambridge University Press: Cambridge.

Curasi CF. 1999. In hope of an enduring gift: the intergenerational transfer of cherished possessions; a special case of gift giving. Advances in Consumer Research 26: 125132.

Curasi CF, Price LL, Arnould EJ. 2004. How individuals' cherished possessions become families' inalienable wealth. Journal of Consumer Research 31(December): 609-622.

Daiute C, Lightfoot C (eds.). 2004. Narrative Analysis: Studying the Development of Individuals in Society. Sage: London.

Dittmar H. 1991. Meanings of material possessions as reflections of identity, in Floyd W. Rudmin (ed.), To Have Possessions: A Handbook on Ownership and Property (Vol. 6: 165-186).

Eckhardt GM, Houston MJ. 2001. To own your grandfather's spirit: the nature of possessions and their meaning in China. Paper presented at the Asia Pacific Advances in Consumer Research, Provo, UT.

Epp AM, Price LL. 2008. Family identity: a framework of identity interplay in consumption practices. Journal of Consumer Research 35 (June): 50-70.

Erikson EH. 1982. The Life Cycle Completed. W. W. Norton: New York.

Fournier S. 1998. Consumers and their brands: developing relationship theory in consumer research. Journal of Consumer Research 24 (March): 343-373.

Gentry J, Baker SM, Kraft FB. 1995. The role of possessions in creating, maintaining, and preserving one's identity: variation over the life course. Paper presented at the Advances in Consumer Research, Provo, UT.

Georgakopoulou A. 2002. Narrative and identity management: discourse and social identities in a tale of tomorrow. Research on Language and Social Interaction 35: 427-451.

Gollwitzer PM, Wicklund RA. 1985. Self-symbolizing and the neglect of others' perspectives. Journal of Personality and Social Psychology 48(3): 702-715.

Hirchman EC, LaBarbera PA. 1990. Dimensions of possession importance. Psychology \& Marketing 7(3): 215-233.

Holman RH. 1983. Possessions and ownership. The semiotics of consumer-behaviour. Paper presented at the Advances in Consumer Research Provo, U.T.

Hwang KK. 1999. Filial piety and loyalty: two types of social identification in Confucianism. Asian Journal of Social Psychology 2: 163-183.

Jankowiak W. 1997. Romantic Passion: A Universal Experience? Columbia University Press: New York.

Joy A. 2001. Gift giving in Hong Kong and the continuum of social ties. Journal of Consumer Research 28 (September): 239-256.

Kamptner NL. 1995. Treasured possessions and their meanings in adolescent males and females. Adolescence 30 (118): 301-318.

Kleine SS, Kleine RE, Allen CT. 1995. How is a possession "me" or "not me"?

Characterizing types and an antecedent of material possession attachment. Journal of Consumer Research 22 (December): 327-343.

Markus HR, Kitayama S. 1991. Culture and the self: implications for cognition, emotion, and motivation. Psychological Review 98(2): 224-253. 
McAlexander JH. 1991. Divorce, the disposition of the relationship, and everything. Paper presented at the Advances in Consumer Research, Provo, UT.

Mehta R, Belk RW. 1991. Artifacts, identity, and transition: favourite possessions of Indians and Indian immigrants to the US. Journal of Consumer Research 17(4): 398-411.

Mick DG, Demoss M. 1990. Self gifts: phenomenological insights from four contexts. Journal of Consumer Research 17 (December): 322-332.

Morris SM. 2001. Joint and individual interviewing in the context of cancer. Qualitative Health Research 11(4): 553-567.

Noble CH, Walker BA. 1997. Exploring the relationships among liminal transitions, symbolic consumption, and the extended self. Psychology \& Marketing 14(1): 29-47.

Olson C. 1985. Materialism in the home: the impact of artifacts on dyadic communication. Paper presented at the Advances in Consumer Research, Provo, UT.

Pahl J. 1989. Money \& Marriage. Macmillan: Basingstoke.

Pierce JL, Kostova T, Dirks KT. 2003. The state of psychological ownership: integrating and extending a century of research. Review of General Psychology 7(1): 84-107.

Price LL, Arnould EJ, Curasi CF. 2000. Older consumers' disposition of special possessions. Journal of Consumer Research 27 (September): 179-201.

Radley A. 1988. Prospects of Heart Surgery: Psychological Adjustments to Coronary Bypass Grafting. Springer: London.

Richins ML. 1994a. Special possessions and the expression of material values. Journal of Consumer Research 21: 522-533.

Richins ML. 1994b. Valuing things: the public and private meanings of possessions. Journal of Consumer Research 21: 504-521.

Rudmin FW. 1994. Gender differences in the semantics of ownership: a quantitative phenomenological survey study. Journal of Economic Psychology 15: 487-510.

Ruth JA, Brunel F, Otnes C. 2004. An investigation of the power of emotions in relationship realignment: the gift recipient's perspective. Psychology and Marketing 21(1): 29-52.

Ruth JA, Otnes CC, Brunel FF. 1999. Gift receipt and the reformulation of interpersonal relationships. Journal of Consumer Research 25 (March): 385-402.

Sayer A. 1992. Method in Social Science: A Realist Approach. Routledge: London.

Schultz SE, Kleine RE, Kernan JB. 1989. "These are a few of my favorite things" toward an explication of attachment as a consumer behavior construct. Advances in Consumer Research 16: 359-366.

Stern BB, Thompson CJ, Arnould EJ. 1998. Narrative analysis of a marketing relationship: the consumer's perspective. Psychology \& Marketing 15(3): 195-214.

Taylor C. 1989. Sources of the Self: The Making of Modern Identity. Cambridge University Press: Cambridge

Therkelsen A, Gram M. 2008. The meaning of holiday consumption: construction of self among mature couples. Journal of Consumer Culture 8(2): 269-292.

Tian K, Belk RW. 2005. Extended self and possessions in the workplace. Journal of Consumer Research 32(2): 297-310.

Wagner I, Wodak R. 2006. Performing success: Identifying strategies of self-presentation in women's biographical narratives. Discourse and Society 17(3): 385-411.

Wallendorf M, Arnould EJ. 1988. "My favorite things": a cross-cultural inquiry into object attachment, possessiveness, and social linkage. Journal of Consumer Research 14: 531-547.

Wong P, Hogg MK. 2010. "My possessions are mine and your possessions are mine too." Using Hong Kong Chinese consumers' narratives to illuminate the boundaries between extended possessions and the extended self. Paper presented at the Advances in Consumer Research, Duluth, MN. 
Yang MH. 1994. Gifts, Favors and Banquets: The Art of Social Relations in China. Cornell University Press: Ithaca, NY.

Young MM. 1991. Disposition of possessions during role transitions. Paper presented at the Advances in Consumer Research, Provo, UT. 


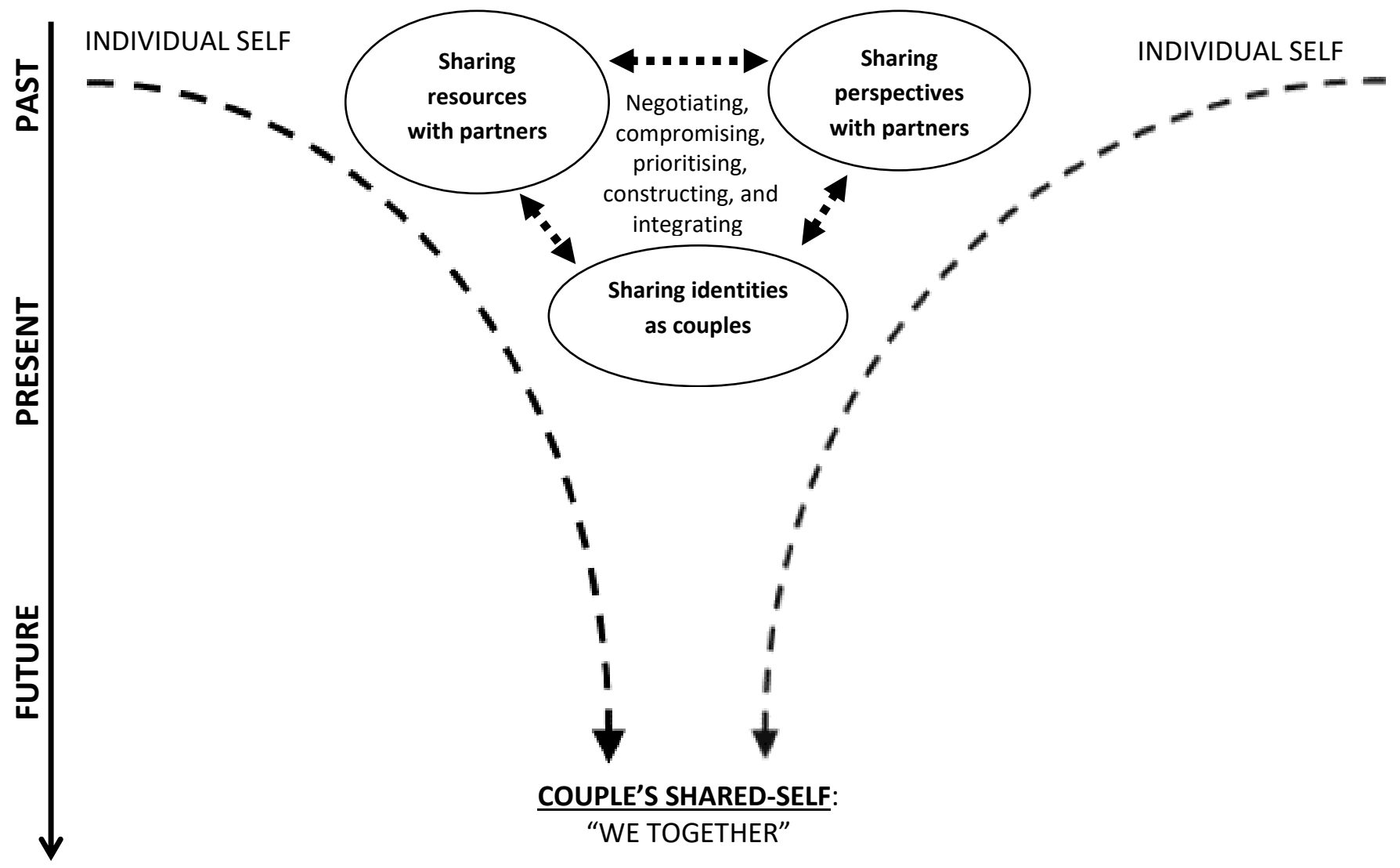

Figure 1: A Temporal Model of Couples' Shared-Self 